\title{
СТВОРЕННЯ СУЧАСНОГО ПІДРУЧНИКА - ЗАПОРУКА ПІДВИЩЕННЯ ЕФЕКТИВНОСТІ НАВЧАЛЬНОГО ПРОЦЕСУ
}

\author{
О. П. Волосовець, Ю. С. П'ятницький, І. С. Вітенко, І. В. Мельник \\ Міністерство охорони здоров'я Украӥни, \\ Центральний методичний кабінет з вищої медичної освіти
}

\section{CREATION OF MODERN TEXTBOOK IS A PLEDGE OF EDUCATIONAL PROCESS EFFICACY}

\author{
O. P. Volosovets, Yu. S. Pyatnytskyi, I. S. Vitenko, I. V. Melnyk \\ Ministry of Public Health of Ukraine, \\ Central Methodological Office of Higher Medical Education
}

\begin{abstract}
У статті висвітлено необхідність підготовки якісної сучасної навчальної книги - однієї з основних складових підготовки медичних і фармацевтичних кадрів.

У роботі розкрито основні вимоги до сучасних підручників та посібників, які повинні забезпечувати, перш за все, керування самостійною позааудиторною підготовкою студентів, обсяг якої при переході на кредитно-модульну систему навчання значно зріс.
\end{abstract}

The article reflects the necessity of preparing of modern textbook that is important for educating of medical and pharmaceutical specialists. The article adduces the main requirements for the modern textbooks, especially in the light of increased demands to the students' self-educating while implementation of credit-modular system of education.

Вступ. Забезпечення студентів сучасними підручниками та посібниками, підготовленими відповідно до оновлених навчальних програм 3 урахуванням новітніх здобутків світової та вітчизняної медичної науки, залишається однією з основних складових покращання якості підготовки фахівців для медичної галузі.

Основна частина. Щорічний моніторинг забезпечення навчальних дисциплін підручниками та посібниками, що проводиться Центральним методичним кабінетом з вищої медичної освіти МОЗ України, свідчить, що станом на 1 вересня 2010 року порівняно з 2008 та 2009 роками знизився середній показник в Україні щодо забезпечення студентів підручниками та посібниками, виданими державною мовою протягом останніх років, тобто підручниками - $32 \%$, посібниками - $33 \%$ (табл. 1).

Протягом останніх років залишається найменш забезпеченим підручниками та посібниками блок гуманітарних та соціально-економічних дисциплін (підручниками - $16 \%$ порівняно $330 \%$ у 2008 році та посібниками - $31 \%$ порівняно $339 \%$ у 2008 році).

Найкраще забезпечені навчальною книгою дисципліни блоку природничо-наукової підготовки (підручниками - на $43 \%$ порівняно з $58 \%$ у 2008 році, посібниками - на $37 \%$ порівняно з $44 \%$ у 2008 році).

Показники забезпечення підручниками та посібниками з професійно-орієнтованих дисциплін становлять $36 \%$ (порівняно з $41 \%$ у 2008 році та $30 \%$ у 2009 році). Найменше забезпечені оновленими підручни-

Tаблиця 1. Забезпечення студентів підручниками та посібниками, виданими державною мовою з грифами МОН, МОЗ, ЦМК з ВМО МОЗ України

\begin{tabular}{|c|c|c|}
\hline Рік & Забезпечення підручниками (\%) & Забезпечення посібниками (\%) \\
\hline 2008 & 43 & 44 \\
\hline 2009 & 47 & 58 \\
\hline 2010 & 32 & 33 \\
\hline
\end{tabular}

(С О. П. Волосовець, Ю. С. П’ ятницький, І. С. Вітенко, І. В. Мельник 
ками та посібниками, підготовленими державною мовою, такі професійно-орієнтовані дисципліни: патоморфологія $(25 \% / 25 \%)$, радіологія $(22 \% / 42 \%)$, біостатистика (32\%/ $2 \%)$, урологія (17\%/13 \%), офтальмологія (7\%/40 \%), судова медицина (14\%/26\%), медичне законодавство (12\%/14 \%), інфекційні хвороби (14\%/58 \%), епідеміологія (6\%/35\%), анестезіологія та інтенсивна терапія (23\%/20\%) тощо.

Як вже наголошувалось Кабінетом раніше, позитивні зрушення вказаних показників можливі за умови збільшення у навчальних закладах видатків на видання та закупівлю навчальної літератури [1].

Відповідно до матеріалів, поданих у ЦМК з ВМО навчальними закладами в січні 2011 року, найбільшу кількість підручників, посібників з відповідними грифами МОН, МО3 та ЦМК з ВМО МОЗ України видано протягом 2010 року в Національному медичному університеті імені О. О. Богомольця (89), Донецькому національному медичному університеті ім. М. Горького (57), Запорізькому державному медичному університеті (46), Львівському національному медичному університеті ім. Данила Галицького (36) (табл. 2).

Необхідно зазначити, що після внесення змін до Порядку присвоєння вченого звання професора і доцента (Постанова Кабінету Міністрів України від 23 червня 2010 року № 507), відповідно до якого скасовано вимогу щодо обов' язкової наявності публікацій з грифом МОН України, збільшилась кількість виданої ВМ $(\Phi) Н 3$ навчальної літератури без відповідних грифів (табл. 3).

Наприклад, видано без грифів 13 посібників у Буковинському державному медичному університеті; 7 підручників та 48 посібників у Вінницькому національному медичному університеті ім. М. І. Пирогова; 13 посібників у Дніпропетровській державній медичній академії; 32 посібники в Донецькому національному медичному університеті ім. М. Горького; 28 посібників у Запорізькому державному медичному університеті; 2 підручники в Івано-Франківському національному медичному університеті; 14 підручників у Кримському державному медичному університеті iм. С. І. Георгієвського; 31 посібник у Львівському національному медичному університеті ім. Д. Галицького; 6 підручників та 48 посібників у Національному медичному університеті імені О. О. Богомольця; 5 підручників та 24 посібники в Національному фармацевтичному університеті; 3 посібники в Одеському національному медичному університеті; 28 посібників у Тернопільському державному медичному університеті імені І. Я. Горбачевського; 1 підручник та 44 посібники в Українській медичній стоматологічній академії; 1 підручник та 12 посібників у Харківському національному медичному університеті.

Таблиця 2. Кількість навчальних книг з відповідними грифами МОЗ, МОН та ЦМК з ВМО МОЗ України, виданих у 2010 році

\begin{tabular}{|c|c|c|c|}
\hline Назва навчального закладу & Підручники & Посібники & $\begin{array}{c}\text { Довідники, } \\
\text { словники }\end{array}$ \\
\hline Буковинський державний медичний університет & $3(3)$ & $44(33)$ & - \\
\hline $\begin{array}{l}\text { Вінницький національний медичний університет } \\
\text { iм. М. І. Пирогова }\end{array}$ & $3(3)$ & $6(5)$ & $5(2)$ \\
\hline Дніпропетровська державна медична академія & $8(5)$ & $22(19)$ & $11(7)$ \\
\hline $\begin{array}{l}\text { Донецький національний медичний університет } \\
\text { ім. М. Горького }\end{array}$ & $5(4)$ & $52(42)$ & - \\
\hline Запорізький державний медичний університет & $4(4)$ & $35(30)$ & $7(6)$ \\
\hline Івано-Франківський національний медичний університет & $3(3)$ & $14(13)$ & - \\
\hline $\begin{array}{l}\text { Кримський державний медичний університет } \\
\text { iм. С. І. Георгієвського }\end{array}$ & $1(0)$ & $7(2)$ & $2(1)$ \\
\hline Луганський державний медичний університет & - & $8(6)$ & $2(1)$ \\
\hline $\begin{array}{l}\text { Львівський національний медичний університет } \\
\text { iм. Д. Галицького }\end{array}$ & $19(5)$ & $13(12)$ & $4(4)$ \\
\hline Національний медичний університет імені О. О. Богомольця & $31(19)$ & $57(43)$ & $1(1)$ \\
\hline Національний фармацевтичний університет & $2(2)$ & $21(15)$ & $10(8)$ \\
\hline Одеський національний медичний університет & $2(2)$ & $7(3)$ & $1(1)$ \\
\hline $\begin{array}{l}\text { Тернопільський державний медичний університет } \\
\text { імені І.Я. Горбачевського }\end{array}$ & $8(8)$ & $9(9)$ & $8(8)$ \\
\hline Українська медична стоматологічна академія & $9(4)$ & $15(12)$ & $3(3)$ \\
\hline Харківський національний медичний університет & $6(5)$ & $19(15)$ & $4(1)$ \\
\hline
\end{tabular}

Примітка. Дані у ( ) - видання українською мовою. 
Разом $з$ тим, незважаючи на внесення змін до зазначеного Порядку присвоєння вченого звання професора і доцента, останнім часом не зменшилась кількість рукописів, поданих авторами до Міністерства освіти і науки, молоді та спорту України та МО3 України для отримання відповідних грифів-дозволів для використання їх в навчальному процесі як підручник чи посібник [6]. Так, протягом 2010 року було надано 452 дозволи, з них МОН України 234 (24-на підручники, 210 - на навчальні посібники), МО3 України 16 (на підручники), ЦМК з ВМО МОЗ України - 202 (на навчальні та навчально-методичні посібники).
Незважаючи на сучасну економічну ситуацію в державі, у більшості навчальних закладів адміністрацією знайдено кошти на закупівлю навчальної літератури (табл. 4). Протягом останніх трьох років найбілыше коштів було виділено у Національному фармацевтичному університеті, Національному медичному університеті імені О. О. Богомольця, Луганському державному медичному університеті.

На жаль, відсутність державного фінансування на видання підручників і посібників не дає можливості належно забезпечити студентів необхідною сучасною якісною навчальною літературою, оскільки авторські

Taблищя 3. Видавнича діяльність вищих медичних навчальних закладів України у 2010 році

\begin{tabular}{|c|c|c|c|c|c|c|}
\hline $\begin{array}{c}\text { Назва навчального } \\
\text { закладу }\end{array}$ & Підручники & Посібники & $\begin{array}{c}\text { Довідники, } \\
\text { словники }\end{array}$ & Монографії & \begin{tabular}{|c|} 
Метод. \\
вказівки, \\
метод. \\
рекомендації \\
\end{tabular} & $\begin{array}{l}\text { Електронні } \\
\text { посібники }\end{array}$ \\
\hline $\begin{array}{l}\text { Буковинський державний } \\
\text { медичний університет }\end{array}$ & $3(3)$ & 57(43) & - & 19(18) & - & - \\
\hline $\begin{array}{l}\text { Вінницький національний } \\
\text { медичний університет } \\
\text { iм. М. І. Пирогова } \\
\end{array}$ & $10(8)$ & $54(37)$ & $5(2)$ & $11(6)$ & $53(41)$ & - \\
\hline $\begin{array}{l}\text { Дніпропетровська державна } \\
\text { медична академія }\end{array}$ & $8(5)$ & $35(24)$ & $11(7)$ & $9(4)$ & $10(8)$ & - \\
\hline $\begin{array}{l}\text { Донецький національний } \\
\text { медичний університет } \\
\text { iм. М. Горького } \\
\end{array}$ & $5(4)$ & $84(48)$ & - & $41(14)$ & $95(48)$ & $16(14)$ \\
\hline $\begin{array}{l}\text { Запорізький державний } \\
\text { медичний університет }\end{array}$ & $4(4)$ & $63(25)$ & $7(6)$ & $9(2)$ & $86(27)$ & \\
\hline $\begin{array}{l}\text { Івано-Франківський національ- } \\
\text { ний медичний університет }\end{array}$ & $5(4)$ & $14(13)$ & - & $10(10)$ & $38(26)$ & - \\
\hline $\begin{array}{l}\text { Кримський державний медич- } \\
\text { ний університет } \\
\text { iм. С. І. Георгієвського }\end{array}$ & $15(5)$ & $87(16)$ & $3(1)$ & - & $25(0)$ & - \\
\hline $\begin{array}{l}\text { Луганський державний } \\
\text { медичний університет }\end{array}$ & - & $8(6)$ & $2(1)$ & $1(0)$ & $48(25)$ & - \\
\hline $\begin{array}{l}\text { Львівський національний } \\
\text { медичний університет } \\
\text { iм. Д. Галицького }\end{array}$ & $19(5)$ & $44(42)$ & $4(4)$ & $18(16)$ & $111(88)$ & - \\
\hline $\begin{array}{l}\text { Національний медичний } \\
\text { університет } \\
\text { імені О. О. Богомольця }\end{array}$ & $37(22)$ & $105(76)$ & $6(5)$ & $30(22)$ & $10(8)$ & 1 \\
\hline $\begin{array}{l}\text { Національний } \\
\text { фармацевтичний університет }\end{array}$ & $7(3)$ & $45(24)$ & $10(8)$ & $14(11)$ & $45(44)$ & \\
\hline $\begin{array}{l}\text { Одеський національний } \\
\text { медичний університет }\end{array}$ & $2(2)$ & $10(7)$ & $1(1)$ & $6(1)$ & $7(4)$ & $3(3)$ \\
\hline $\begin{array}{l}\text { Тернопільський державний } \\
\text { медичний університет } \\
\text { iмені І. Я. Горбачевського }\end{array}$ & $8(8)$ & $37(37)$ & $8(8)$ & $3(3)$ & $2(2)$ & \\
\hline $\begin{array}{l}\text { Українська медична } \\
\text { стоматологічна академія }\end{array}$ & $10(4)$ & $59(34)$ & $3(3)$ & 1(1) & $27(16)$ & $1(1)$ \\
\hline $\begin{array}{l}\text { Харківський національний } \\
\text { медичний університет }\end{array}$ & $7(5)$ & $31(17)$ & $4(1)$ & $11(5)$ & $130(71)$ & - \\
\hline
\end{tabular}

Примітка. Дані у ( ) - видання українською мовою. 
Таблиця 4. Дані про кошти, направлені ВМНЗ на закупівлю навчальної літератури протягом 2008-2010 років

\begin{tabular}{|l|c|c|c|}
\hline \multicolumn{1}{|c|}{ Назва навчального закладу } & $\mathbf{2 0 0 8}$ рік & $\mathbf{2 0 0 9}$ рік & $\mathbf{2 0 1 0}$ рік \\
\hline Буковинський державний медичний університет & 207692,20 & 16037,80 & 206633,04 \\
\hline $\begin{array}{l}\text { Вінницький національний медичний } \\
\text { університет ім. М. І. Пирогова }\end{array}$ & 422791,21 & 138400,00 & 251369,10 \\
\hline Дніпропетровська державна медична академія & 247774,30 & 130492,91 & 302996,70 \\
\hline $\begin{array}{l}\text { Донецький національний медичний університет } \\
\text { ім. М. Горького }\end{array}$ & 219264,00 & 306656,70 & 252727,80 \\
\hline Запорізький державний медичний університет & 155671,99 & 382367,24 & 111067,50 \\
\hline $\begin{array}{l}\text { Івано-Франківський національний медичний } \\
\text { університет }\end{array}$ & 232026,90 & 167797,60 & 31248,74 \\
\hline $\begin{array}{l}\text { Кримський державний медичний університет } \\
\text { ім. С. І. Георгієського }\end{array}$ & 210201,49 & 31209,13 & 1196129,20 \\
\hline Луганський державний медичний університет & 446017,28 & 564122,20 & 402120,40 \\
\hline $\begin{array}{l}\text { Львівський національний медичний університет } \\
\text { ім. Д. Галицького }\end{array}$ & 590433,00 & 174151,21 & 2189140,50 \\
\hline $\begin{array}{l}\text { Національний медичний університет } \\
\text { імені О. О. Богомольця }\end{array}$ & 1732674,6 & 808155,00 & 533385,23 \\
\hline Національний фармацевтичний університет & & & 2889012,04 \\
\hline Одеський національний медичний університет & 315813,81 & 911133,52 & 158751,00 \\
\hline $\begin{array}{l}\text { Тернопільський державний медичний } \\
\text { університет імені І. Я. Горбачевського }\end{array}$ & 190087,00 & 140606,60 & 223600,00 \\
\hline Українська медична стоматологічна академія & 384769,41 & 98930,00 & 314462,50 \\
\hline $\begin{array}{l}\text { Харківський національний медичний } \\
\text { університет }\end{array}$ & 47450,00 & 204136,50 & \\
\hline
\end{tabular}

колективи не завжди мають можливість знайти достатньо спонсорських коштів, тому підготовка і видання підручників нового типу підмінюеться підготовкою і виданням навчальних книг невеликим тиражем.

Необхідно підкреслити, що видавати підручники та посібники не встигають за надто частими змінами навчальних планів та програм. При цьому зміни навчальних програм передбачають значне зменшення годин аудиторних занять, разом з тим збільшується обсяг самостійної позааудиторної роботи студента. Останнє зумовлює необхідність видавати підручники, які б компенсували недостатню кількість лекцій та семінарів.

Основними недоліками навчальної літератури є: компіляція вже надрукованого матеріалу, низький науково-теоретичний рівень рукописів, використання невідредагованих машинних перекладів з іноземних джерел, практична відсутність власних джерел. Враховуючи це, Міністерство освіти і науки України направило лист від 01.10.10 № 1/9-776 за підписом Міністра освіти і науки України Д. В. Табачника ректорам (директорам) вищих навчальних закладів I-IV рівнів акредитації “Щодо якості навчальної літератури", у якому наголошується на персональній відповідальності керівників вищих навчальних закладів за використання у навчально-виховному процесі неякісної навчально-методичної літератури [5].
Міністерство охорони здоров'я України листом від 11.02.2009 № 08.01-47/255 до ректорів вищих медичних (фармацевтичного) навчальних закладів IV рівня акредитації з метою покращання забезпечення студентів-медиків та фармацевтів сучасною, підготовленою відповідно до діючих стандартів вищої медичної та фармацевтичної освіти й новітніх досягнень медичної науки навчальною книгою доручило посилити контроль за підготовкою оновлених базових міжкафедральних підручників.

Аналіз підходів учених до вирішення даної проблеми дозволяє стверджувати, що пошук шляхів створення сучасної навчальної літератури для студентів вищої школи є наразі актуальним і своєчасним. Серед причин, що заважають ефективному вирішенню проблеми, вказують на відсутність чітких стандартів та критеріїв оцінювання методичної літератури.

Отже, яких вихідних положень варто дотримувати сучасним авторам при формуванні змісту підручника та посібника для вищої школи? За якими показниками слід обирати підручник? Яким вимогам повинен відповідати якісний підручник чи посібник? Сучасний підручник чи посібник для вищої школи повинен містити матеріал для викладання та самостійного опрацювання, відповідно упорядкований за допомогою описів і пояснень, наочних схем, графіків, таблиць. Якісний підручник повинен спрямовувати 
самостійну позааудиторну роботу студентів, здійснюючи синтез вже знайомого й нового матеріалу на різних рівнях узагальнення.

Сучасний посібник має полегшувати студентові пізнавальну роботу, звільняючи його від необхідності постійно нотувати лекцію, а також надаючи можливість повертатись до опрацьованого матеріалу 3 метою повторення. Наприклад, інформативний глосарій з тлумаченням слова чи виразу іноземною мовою, розміщений в посібнику, запобігає необхідності часто звертатись до словника, що економить час i зусилля студента.

Необхідно зазначити, що навчальній літературі має бути притаманна стабільність, тобто можливість користуватись протягом 5 років без значних змін. Це не лише економія коштів, а й показник якості.

Сучасний підручник повинен бути багатофункціональним. Перш за все, він виконує освітню функцію, задовольняючи пізнавальні потреби студента як в процесі освоєння та закріплення навчального матеріалу, так і для його самостійного опанування. В межах освітньої функції підручник повинен забезпечувати систематизацію набутих знань та передбачати можливість самоконтролю. Бажано, щоб у підручнику були розміщені матеріали для контролю знань (питання, тести, вправи) і тоді він допоможепри підготовці до заліку чи іспиту [4].

Зміст підручника повинен відповідати змісту навчальної програми, затвердженої Міністерством охорони здоров’я України, авторський посібник - частині навчальної програми (додаток 2 до наказу МОН України № 588 від 27.06.2008 р.) [3].

Підручник повинен виконувати і виховну функцію, оскільки він впливає на світогляд молодої людини, їі ставлення до вибраної професіі, моральні, естетичні, а також патріотичні почуття, сприяє формуванню всебічно розвиненої особистості, яка зможе творчо підходити до виконання професійних і життєво важливих завдань [4].

Розвивальна функція підручника реалізується через вплив на інтелектуальний розвиток студентів пам'яті, мислення, уваги, мовлення, уяви, здібностей тощо. Так, під час роботи з підручником потрібно розвивати критичне мислення, здатність формулювати запитання, аргументувати власну точку зору, вести дискусію, діалог тощо.

Таким чином, ефективність підручника визначається тим, наскільки він забезпечує професійну підготовку студентів, сприяє розвитку пізнавальних інтересів, дає змогу проявити здібності, стимулює творчу активність, допомагає формуванню гармонійно розвиненої особистості спеціаліста європейського рівня.

Якість засвоєння матеріалу залежить і від структури підручника, збалансованості та системності його змісту. Проблема правильного структурування підручника є наразі актуальною. В додатку 1 до наказу Міністерства освіти і науки України від 27.06.2008 № 588 відображена система побудови підручника для вищої школи, що передбачає [2]:

1. Зміст-перелік заголовків рубрик у книзі, які точно повторюють заголовки в тексті.

2. Вступ, що повинен визначити роль та завдання дисципліни при підготовці фахівця, сформулювати завдання, які стоять перед студентом і у вирішенні яких запропонований підручник чи посібник має відігравати провідну роль.

3. Текст підручника не ретранслює наукові дані, а навчає способів самостійного опанування знаннями та поповнення їх. Він має поступово перетворюватись в інтелектуальний самовчитель, бути орієнтиром для навчальних здібностей студента.

Так, в текстах для студентів медичного профілю необхідна реалізація трьох основних принципів: автентичності, професійної інтеграції та стабільності. Апарат організації засвоєння - питання, тексти, задачі, завдання, інструктивні матеріали тощо-має на меті, перш за все, полегшити самостійну роботу студента, надати йому можливість не тільки засвоїти теоретичний матеріал, а й набути практичних навичок $\mathrm{i}$ перевірити їх.

4. Ілюстративний матеріал, який підсилює емоційний, естетичний, пізнавальний вплив навчального матеріалу, допомагає студентові краще засвоїти додаткову інформацію.

5. Бібліографічний опис, що містить список використаних джерел та рекомендовану літературу для поглибленого вивчення курсу.

6. Довідковий матеріал, який є сукупністю визначених термінів та понять, їх розуміння забезпечує свідоме засвоєння змісту навчального матеріалу. У підручнику чи посібнику також слід представити іменний покажчик з переліком і характеристикою імен, які зустрічаються в книзі. Прикладом можебути глосарій.

7. Додатки, які збагачують зміст підручника, доповнюють та ілюструють матеріал, гармонійно вписуючись в основний зміст, дають можливість перевірити засвоєні знання, розвивають здатність до самостійної творчої роботи та самоконтролю.

Отже, структура підручника чи посібника відіграє одну з провідних ролей в оцінці його ефективності й, 
водночас є вимогою і важливою умовою успіху в написанні навчальної книги.

Міністерством охорони здоров'я України з метою покращання забезпечення студентів вищих медичних (фармацевтичного) навчальних закладів сучасними підручниками, підготовленими державною мовою, відповідно до оновлених навчальних програм, наказом МО3 України від 22.06.2010 № 502 “Про затвердження робочих груп 3 питань підготовки національних підручників для студентів вищих навчальних закладів IV рівня акредитації, підпорядкованих MO3 України", доручено провідним фахівцям ВМ(Ф)НЗ сформувати авторські колективи для підготовки базових підручників з усіх дисциплін діючих навчальних планів підготовки лікарів та фармацевтів. Оскільки відповідно до чинного законодавства викладання у вищих навчальних закладах здійснюється українською мовою, у вказаному наказі базовий підручник названо національним.

Цим наказом було затверджено склад координаційної групи та робочих груп з підготовки єдиних національних підручників, до яких увійшли завідувачі опорних кафедр та провідні фахівці галузі.

МО3 України листом від 25.10.2010 № 08-01-47/2361 було доручено ректорам вищих медичних (фармацевтичного) навчальних закладів організувати проведення міжкафедральних нарад завідувачів однопрофільних кафедр та відповідно до їх пропозицій сформувати авторські колективи для підготовки національних підручників, як це передбачено у наказі MO3 України від 22.06.2010 № 502. Дані пропозиції $\mathrm{BM}(\Phi) Н 3$ були розглянуті та обговорені на засіданні Комісії з медицини МОН України.

Для більш конкретного визначення змісту підручників Центральним методичним кабінетом з вищої медичної освіти МО3 України (лист від 11.02.2011 № 23-01-9/28) авторським колективам запропоновано підготувати плани-проспекти та анотації. На підставі вказаних матеріалів підготовлено перелік державних базових підручників для вищих медичних (фармацевтичного) навчальних закладів IV рівня акредитації та план видання їх на 2011-2013 роки.

Міністерство охорони здоров' я України сподівається на покращання економічної ситуації в державі й на те, що все ж таки буде відновлено державне фінансування на видання навчальної літератури, в тому числі і для студентів-медиків та фармацевтів.

В Указі Президента України від 30.10.2010 p. № 926/2010 “Про заходи щодо забезпечення пріоритетного розвитку освіти в Україні” доручено Кабінету Міністрів України (р. 3, п. 22) здійснити заходи щодо удосконалення порядку забезпечення навчальною літературою студентів вищих навчальних закладів. У наказі Міністерства освіти і науки України від 20.12.2010 № 1258 “Щодо плану реалізації завдань, визначених розпорядженням Кабінету Міністрів України від 27 серпня 2010 р. № 1728 “Про затвердження плану заходів щодо розвитку вищої освіти на період до 2015 року” є відповідний пункт (п. 2) - “Забезпечити видання навчальної літератури для вищих навчальних закладів, у тому числі на електронних носіях".

Висновок. Таким чином, вирішення проблеми підготовки якісних базових підручників 3 дисциплін навчальних планів додипломної підготовки фахівцівмедиків та фармацевтів усіх спеціальностей можливе за умови завершення підготовки оновлених галузевих стандартів та типових навчальних програм, а також відновлення державного фінансування видання навчальної літератури для студентів.

\section{Лiтература}

1. Вітенко I. С. Стан та проблеми забезпечення студентівмедиків сучасною навчальною книгою / I. С. Вітенко // Матеріали Всеукр. навч.-наук. конф. "Проблеми інтеграції української медичної освіти у світовий освітній простір" (21-22 травня 2009 р.). - Тернопіль : Укрмедкнига, 2009.

2. Щодо видання навчальної літератури для вищої школи : додаток 1 до наказу МОН України від 27.06.2008 p. № 588 .

3. Щодо видання навчальної літератури для вищої школи : додаток 2 до наказу МОН України від 27.06.2008 р. № 588 .
4. Зотова-Садило О. Сучасні підходи до створення навчальної літератури для студентів економічних спеціальностей / О. Зотова-Садило // Наукові записки. Серія : Педагогічні науки . - 2010. - Вип. 88. - С.116-119.

5. Щодо якості навчальної літератури : лист Міністерства освіти і науки України від 01.10.10 № 1/9-776.

6. Про внесення змін до Порядку присвоєння вченого звання професора і доцента : Постанова Кабінету Міністрів України від 23 червня 2010 р. № 507. 